\title{
Analysis of PTEN Methylation Pattern by Pyrosequencing in Renal Cell Carcinoma
}

\author{
Eurico Cleto Ribeiro de Campos ${ }^{1 *}$, Marcos Gonçalves Adriano Júnior ${ }^{1}$, \\ Marcus Rivabem Winheski², Renan Martins ${ }^{3}$, Ademar Lopes ${ }^{4}$ \\ ${ }^{1}$ Department of Oncology Surgery of Prevent Senior São Paulo Group, São Paulo, Brasil \\ ${ }^{2}$ Oncology Surgical Department of Evangélico Mackenzie University Hospital, Curitiba, Paraná \\ ${ }^{3}$ Ponta Grossa State University, Paraná, Brasil \\ ${ }^{4}$ Hospital A. C. Camargo, São Paulo, Brazil \\ Email: *euricocrcampos@gmail.com, marcos.adriano@preventsenior.com.br, mrivabem@yahoo.com.br, \\ martinsrenanmd@gmail.com, ademar-lopes@uol.com.br
}

How to cite this paper: de Campos, E.C.R., Adriano Júnior, M.G., Winheski, M.R., Martins, R. and Lopes, A. (2020) Analysis of PTEN Methylation Pattern by Pyrosequencing in Renal Cell Carcinoma. Journal of Cancer Therapy, 11, 793-802. https://doi.org/10.4236/jct.2020.1112069

Received: August 17, 2020

Accepted: December 12, 2020

Published: December 15, 2020

Copyright $\odot 2020$ by author(s) and Scientific Research Publishing Inc. This work is licensed under the Creative Commons Attribution International License (CC BY 4.0).

http://creativecommons.org/licenses/by/4.0/

\begin{abstract}
Objectives: We aimed to determine the frequency of PTEN (phosphatase with tensin homology deleted in chromosome 10) hypermethylation in renal cell carcinoma (RCC) and its impact on overall (OS) and disease-free survival (DFS). The association between PTEN hypermethylation and clinic and pathologic factors was also analyzed. Materials and Methods: The authors analyzed 137 patients who had undergone a radical or partial nephrectomy between 1997 and 2011. The methylation pattern was quantified individually at multiple $\mathrm{CpG}$ islands that are located on the exon 1 of PTEN gene by pyrosequencing. Results: Mean follow-up was 32.3 months. PTEN hypermethylation was detected with a low frequency $(3.6 \%)$. There were no deaths or disease recurrence among patients with PTEN hypermethylation. Determining the association between PTEN hypermethylation and clinical and pathological factors was not possible due to the low frequency observed. Conclusion: The results show that the methylation of promoter CpG sites in PTEN is relatively infrequent in renal carcinogenesis and has no prognostic impact on survival.
\end{abstract}

\section{Keywords}

Methylation, PTEN, Pyrosequencing, Renal Cell Carcinoma

\section{Introduction}

Renal cell carcinoma (RCC) in some countries is one of the 10 most frequent malignancies [1]. Despite the more frequent diagnosis of increasingly smaller 
and asymptomatic renal tumors, approximately $30 \%$ to $50 \%$ of patients have metastases at the time of diagnosis or will develop during the course of the disease, even with localized disease [1] [2].

Studies have been conducted to identify different biomarkers that are more able to predict the risk of progression or death by this disease and to identify patients who may better respond to treatment [2].

Among the genes studied, PTEN (phosphatase with tensin homology deleted in chromosome 10) is notable. It is a tumor suppressor gene located on chromosome 10q23 that can be inactivated due to mutations, deletions or hypermethylation in different solid tumors [3].

The methylation of the promoter region of DNA is one of the epigenetic mechanisms of inactivation of gene expression and because its epigenetic origin is a potential target for therapies to reverse the methylation phenotype [4]. In RCC, the frequency of mutation has been found to range from $0 \%$ to $7.5 \%$, and hypoexpression identified using immunohistochemistry has been found to range from $33 \%$ to $39 \%$, but the methylation profile is unknown [5]-[11]. In the literature, there are few reports of epigenetic alterations in RCC.

The aim of this study was to evaluate the profile of PTEN gene methylation using pyrosequencing, the frequency of methylation, the impact on overall survival (OS) and disease-free survival (DFS) and the association of the findings with clinical and pathological factors commonly used in RCC.

\section{Materials and Methods}

Retrospectively, 137 patients with histologically proven RCC at stages T1 to T4, $\mathrm{N} 1$ to N2 and with or without distant metastasis at diagnosis were analyzed, treated from 1997 to 2011. All patients received surgical treatment for the neoplasm which consisted of radical or partial nephrectomy. The criteria established for the exclusion of patients in the study were: 1) treatment in different hospital, 2) patients undergoing other types of cancer treatments (immunotherapy, chemotherapy, hormone therapy, radiotherapy), 3) material stored in paraffin in poor condition for preparation of the tissue microarray, 4) patients with severe comorbidities that limited their life expectancy or who had another active malignancy. The mean follow-up was 32.3 months.

PTEN methylation was performed on tumor samples from these patients that were collected intraoperatively. The most representative samples that were free of necrotic and fibrotic areas were rapidly frozen in liquid nitrogen and stored at $-80^{\circ} \mathrm{C}$ in the tumor bank.

For manual microdissection, fifteen 5- $\mu \mathrm{m}$ sections were made for each tumor sample available in the tumor bank. One of the sections was immediately stained with hematoxylin-eosin to assess the amount of tumor and to demarcate the area to be submitted to manual extraction, considering that there is always much more than $70 \%$ of tumoral cells in the sample for extraction. All samples were reviewed by a single pathologist. For DNA extraction, the QIAamp DNA Micro 
kit (Qiagen, Uniscience, Brazil) was used according to the manufacturer's guidelines. Extracted DNA was quantified by spectrophotometry in the NanoDrop ND-1000 (NanoDrop Technologies, Delaware, USA). To verify the integrity of the extracted DNA, $200 \mathrm{mg}$ of each sample was resolved on an agarose gel.

The Fuhrman (1982) classification system was used: grade I and II tumors were considered low-grade, and grade III and IV tumors were classified as high grade [12]. To define the histological subtype, the World Health Organization (2004) classification was used [13]. Patients were analyzed in two groups: stages I and II (localized disease) and stages III and IV (locally advanced or metastatic disease) according to TNM 2004 [14].

\subsection{Methylation Detection}

After extraction, $1 \mu \mathrm{g}$ of tumor DNA from each sample was treated with sodium bisulfite using an EZ DNA Methylation kit (Zymo Research) [15]. Treatment with sodium bisulfite promotes the deamination of nonmethylated cytosines by converting them into uracils, whereas methylated cytosines remain unchanged.

As a quality control in treatment of DNA with bisulfite, a fragment of the beta-actin gene was amplified using the primers designed for beta-actin gene after treatment with sodium bisulfite: 5'-TGGTGATGGAGGAGGTTTAGTAAGT-3' and 3'-AACCAATAAAACCTACTCСТCССТTAA-5.

For the reaction, $2 \mu \mathrm{l}$ of diluted DNA, $2.5 \mu \mathrm{l}$ of 10X buffer reaction, $1 \mu \mathrm{l}$ of $\mathrm{MgCl} 2(1.5 \mathrm{mM}), 0.5 \mu \mathrm{l}$ of dNTPs (10 mM) (Invitrogen), 1.0 of each primer (10 $\mathrm{mM}$ ) and 0.2 of Taq DNA Polymerase Platinum (Invitrogen) were used, for a final reaction volume of $25 \mu \mathrm{l}$. The following amplification conditions were used: initial denaturation for 5 minutes at $95^{\circ} \mathrm{C}, 35$ cycles at $60^{\circ} \mathrm{C}$ for 1 minute, $72^{\circ} \mathrm{C}$ for 1 minute, $72^{\circ} \mathrm{C}$ for 7 minutes with a final elongation step of $72^{\circ} \mathrm{C}$ for $7 \mathrm{mi}$ nutes. The reaction was assessed by performing a spectrophotometric reading using the NanoDrop ND-100 0 (NanoDrop Technologies, Wilmington, DE) and an agarose gel.

To determine PTEN methylation pattern, the Human PTEN CpG methylation kit (Epigendx, USA) was used. Two primers evaluated $27 \mathrm{CpG}$ sites located between codons 795 to 606 of PTEN. The CpG islands 1 to 11 were assessed by primer 5'-GTYGTTGTGAGGYGAGGTYGGGTTTAGGYGAGGGAGATGAGA GAYGGYGGYGGTYGYGGTYGGAGTTTTTTTTAGYGTTTGTGAGTAGT-3' (ADS955FS1) and CpG islands from 12 to 27 by the primer 5'-GTYGYGGGGG TAGYGTTTTYGGGGAGTYGGTYGGTTTGYGGYGGYGGTAGYGGYGGYG TTTTTYGTTTTTTTTTYGTTTTTTTTAATYGTGTAGTTTTTTTTTYGGTTT TTTTTGAAAGGGAAGGTGGA-3'. Lymphocyte DNA methylated in vitro and treated with sodium bisulfite was used as a reaction control.

Preparation of single-stranded DNA for pyrosequencing was performed using the PSQ Vacuum Prep Tool (Qiagen, Valencia, CA) according to the manufacturer's instructions. Twenty-five $\mu$ of the PCR product was immobilized on streptavidin-coated Sepharose beads (Streptavidin Sepharose High Performace, 
GE Healthcare).

In a 96-well plate, $25 \mu \mathrm{l}$ of PCR amplified product was mixed with $55 \mu \mathrm{l}$ of Sepharose bead mix ( $3 \mu \mathrm{l}$ of Sepharose beads, $40 \mu \mathrm{l}$ of binding buffer and $15 \mu \mathrm{l}$ of deionized water) in each well. The plate was shaken for $15 \mathrm{~min}$ at $1350 \mathrm{rpm}$ and then transferred to a vacuum pump (Vacuum Prep Toll) where the PCR product linked to the beads was precipitated with $70 \%$ alcohol, denatured in denaturing buffer and washed in washing buffer.

Then, the purified products were incubated with $0.4 \mu \mathrm{mol} / \mathrm{L}$ of sequencing primers previously diluted in $38.6 \mu \mathrm{l}$ of annealing buffer at $80^{\circ} \mathrm{C}$ for $2 \mathrm{~min}$ in a sequencing plate (PSQ 96 plate), 5 minutes on the hotplate and 5 minutes at room temperature.

The purified products linked to the sequencing primer were transferred to the base of the PSQ HS 96 A Pyrosequencer (Qiagen, Valencia, CA), where the sequencing of PTEN was performed in real time using PyroGold reagents (Qiagen, Valencia, CA).

\subsection{Methylation Analysis}

To determine the methylation pattern of each sample, the rate of methylation (MtI) for each CpG site was measured using the following formula: $\mathrm{mC} /(\mathrm{mC}+$ $\mathrm{C}$ ), where $\mathrm{mC}$ is the number of methylated cytosines, and $\mathrm{C}$ is the number of unmethylated cytosines. The methylated cytosines show a percentage corresponding to the dinucleotide $\mathrm{C}$, and the unmethylated cytosines show a percentage corresponding to the dinucleotide $\mathrm{T}$ [11]. After determining this ratio for each CpG site among the 27 evaluated, a mean of 11 sites evaluated by primer ADS955FS1 and 16 sites assessed by primer ADS955FS2 was obtained.

In this study, PTEN methylation in seven samples of normal renal tissue was evaluated. The CpG sites in normal tissue had a variation of $0 \%$ to $4 \%$, and the mean of these sites led to definition of the cutoff for the presence or absence of methylation. The final MtI corresponded to the mean of the MtI of the CpG islands 1 to 11 and the MtI of the islands 12 to 27. Thus, a MtI equal to or less than 0.04 was considered within the pattern of variability of the unmethylated cases, whereas cases that showed a MtI greater than 0.04 were considered methylated. Figure 1 demonstrates PTEN gene analysis by pyrosequencing.

\subsection{Follow-Up Regimen}

Patients were observed every 3 mo for the first and second year after surgery, every 6 mo from the third through the fifth years, and annually after the fifth year. All medical appointments consisted of a history, a physical examination, serum biochemistry analysis and chest radiography. Abdominal ultrasound and abdominal CT were realized each six mo alternately. Bone scan and nervous system CT are performed when clinically indicated.

At the end of the study, there were 94 patients (68.46\%) alive and without disease, 14 patients $(10.2 \%)$ alive and with disease, 22 deaths (16\%) of which 


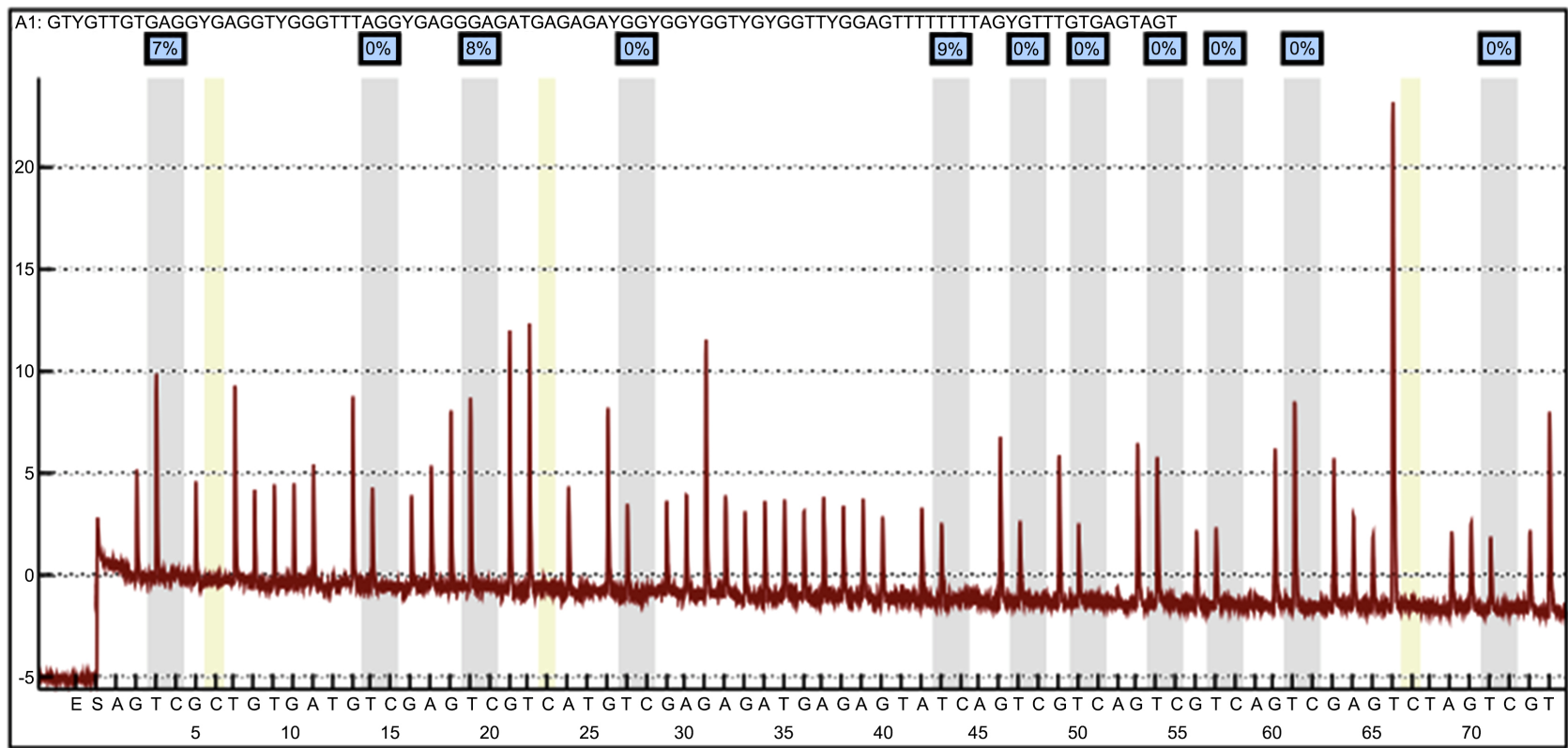

Figure 1. PTEN pyrosequencing analysis.

$15(10.9 \%)$ due to cancer and seven deaths (5.1\%) from other causes. Tumor recurrence was detected in 20 patients (14.6\%) with predominance of patients (85.4\%) without tumor recurrence.

\subsection{Statistical Analysis}

Survival rates were calculated using the Kaplan Meier technique and comparisons between them by the log rank test. Analyses were performed with SPSS v.16.0 (SPSS Inc., Chicago, IL, USA).

\section{Results}

Table 1 shows the main clinicopathological characteristics of the 137 patients analyzed.

Among the 137 cases reviewed, only five (3.6\%) showed PTEN hypermethylation, and 132 (96.4\%) did not. The analysis of the association between PTEN and the main prognostic factors was not possible due to the low frequency of hypermethylation observed (Table 2).

For the five cases showing PTEN hypermethylation, there was no occurrence of any adverse event or death.

\section{Discussion}

Despite the routine use of clinical and pathological criteria to assess the prognosis of patients with RCC, many develop metastases during follow-up, which demonstrates the need to identify new factors to better predict outcome in these patients [1] [2]. 
Table 1. Main clinicopathological characteristics of the 137 patients.

\begin{tabular}{|c|c|c|c|}
\hline Variable & Category & $N$ & $\%$ \\
\hline \multirow[b]{2}{*}{ ECOG } & 0 & 81 & 59.1 \\
\hline & 1.2 & 56 & 40.9 \\
\hline \multirow{2}{*}{$\begin{array}{c}\text { Metastasis at } \\
\text { diagnosis }\end{array}$} & No & 118 & 86.1 \\
\hline & Yes & 19 & 13.9 \\
\hline \multirow{2}{*}{$\begin{array}{l}\text { Symptoms at } \\
\text { diagnosis }\end{array}$} & No & 78 & 56.9 \\
\hline & Yes & 59 & 43.1 \\
\hline \multirow{2}{*}{ Fuhrman Grade } & Lower grade & 89 & 65 \\
\hline & Higher grade & 48 & 35 \\
\hline \multirow{2}{*}{$\begin{array}{l}\text { Histological } \\
\text { subtype }\end{array}$} & Clear cells & 112 & 81.8 \\
\hline & Non-clear cells & 25 & 18.2 \\
\hline \multirow[b]{2}{*}{ EC TNM } & I-II & 98 & 71.5 \\
\hline & III-IV & 39 & 28.5 \\
\hline \multirow{2}{*}{$\begin{array}{c}\text { Microscopic venous } \\
\text { invasion }\end{array}$} & No & 113 & 82.5 \\
\hline & Yes & 24 & 17.5 \\
\hline \multirow{3}{*}{ Recurrence } & No & 117 & 85.4 \\
\hline & Yes & 20 & 14.6 \\
\hline & Total & 137 & $100 \%$ \\
\hline
\end{tabular}

ECOG-European Cooperative Oncology Group.

Table 2. Analysis of PTEN pattern of methylation according to the main prognostic factors.

\begin{tabular}{|c|c|c|c|c|c|c|}
\hline \multicolumn{7}{|c|}{ Methylation } \\
\hline \multirow{2}{*}{ Variable } & \multirow{2}{*}{ Category } & \multicolumn{2}{|c|}{ Hyper } & \multicolumn{2}{|c|}{ Нypo } & \multirow{2}{*}{ Total } \\
\hline & & $\mathrm{n}$ & $\%$ & $\mathrm{n}$ & $\%$ & \\
\hline \multirow{2}{*}{ Symptomatology } & No & 3 & 3.8 & 75 & 96.2 & 78 \\
\hline & Yes & 2 & 3.4 & 57 & 96.6 & 59 \\
\hline \multirow[b]{2}{*}{ ECOG } & 0 & 3 & 3.7 & 78 & 96.3 & 81 \\
\hline & $1 / 2$ & 2 & 3.6 & 54 & 96.4 & 56 \\
\hline \multirow{2}{*}{ Fuhrman grade } & High grade & 1 & 2.1 & 47 & 97.9 & 48 \\
\hline & Low grade & 4 & 4.5 & 85 & 95.5 & 89 \\
\hline \multirow{2}{*}{$\begin{array}{l}\text { Histological } \\
\text { subtype }\end{array}$} & Clear cell & 4 & 3.6 & 108 & 96.4 & 112 \\
\hline & No clear cell & 1 & 4.0 & 24 & 96.0 & 25 \\
\hline \multirow{2}{*}{$\begin{array}{l}\text { Microscopic venous } \\
\text { invasion }\end{array}$} & No & 3 & 2.7 & 110 & 97.3 & 113 \\
\hline & Yes & 2 & 8.3 & 22 & 91.7 & 24 \\
\hline \multirow{2}{*}{ Clinical TNM stage } & $\mathrm{I} / \mathrm{II}$ & 4 & 4.1 & 94 & 95.9 & 98 \\
\hline & III/IV & 1 & 2.6 & 38 & 97.4 & 39 \\
\hline
\end{tabular}

ECOG-Eastern Cooperative Oncology Group. 
The PTEN/MMCA1 gene is located on chromosome 10q23, controls cell migration, proliferation and apoptosis through the downregulation of PI3K (phosphatidylinositol 3-OH kinase) and Akt, and is one of the major genes involved in renal carcinogenesis [1] [2]. The presence of hypoexpression by immunohistochemistry is associated with high histological grade tumors, and lower rates of SLD and its inactivation brings about higher activity of promitotic molecules that are the targets of current treatments for metastatic RCC [8] [9].

In this study, PTEN hypermethylation was identified with a 3.6\% frequency among the 137 samples analyzed. In the gastric and salivary glands, cases of gene methylation were not identified, whereas in glioblastoma multiforme, uterine, cervical, and soft tissue sarcomas, melanoma, and ovarian and breast cancer, PTEN methylation was found in $35 \%, 26 \%, 12 \% 62 \%, 58 \%$ and $14.3 \%$, respectively [16]-[22].

The different frequencies can be explained by the pathways of carcinogenesis specific to each neoplasm, exposure to environmental factors, the method employed to analyze and interpret the results and the PTEN primer used in each study [23] [24] [25] [26].

Pyrosequencing and MS-PCR are the main methods used to assess methylation in the literature. However, MS-PCR may detect higher methylation frequencies compared to pyrosequencing because of false positive results ensuing from this non-quantitative analysis [25]. The choice of PTEN primer is as important as the choice of methodology used to avoid false positive results by differentiating the true gene and pseudogene located on chromosome 9p21, which share $98 \%$ of the same nucleotide sequence [26].

Hypoexpression of the PTEN protein in RCC has been reported in the literature, with frequencies ranging from $33 \%$ to $39 \%$ [8] [9] [10] [11]. The absence or low protein expression of PTEN in these studies may be explained mainly by the occurrence of mutation, deletion and/or hypermethylation.

Sakurada et al. [4] did not detect PTEN mutations in 24 cases of RCC. In 50 samples of RCC tumors, Sukosd et al. [7] did not find mutations in the PTEN gene either. Kondo et al. [6] evaluated 68 samples of RCC and identified five cases $(7.5 \%)$ of PTEN mutation and a $25 \%$ loss of heterozygosity. Morita et al. [27], Teng et al. and Velickovic et al. [28] showed a loss of heterozygosity in 41, $40 \%$ and $37.5 \%$, respectively, of the analyzed RCC samples.

The loss of heterozygosity shown in these studies substantiates the existence of genetic events that may contribute to the absence or low protein expression of PTEN. PTEN mutation is rare in RCC, occurring at frequencies lower than $7.5 \%$. Although this study did not analyze the PTEN protein, the low frequency of methylation detected in this study suggests that PTEN hypermethylation is not the primary mechanism of inactivation.

Oncogenic miRNA is a recently described mechanism that can contribute to lower expression of the gene PTEN in RCC. Zaman et al. [29] demonstrated an association between lower expression of the PTEN gene and high activity of on- 
cogenic miR-23b-3p. High levels of miR-23b-3p were determinants of lower survival rates in patients with RCC.

There were no deaths or recurrences among the five cases showing PTEN hypermethylation. Studies that have demonstrated the negative impact of changes in PTEN on the survival of patients with RCC were based upon immunohistochemical analysis [1] [8]. Identifying the molecular change is important because mutation and methylation did not prove to be central mechanisms of inactivation in RCC.

In lung cancer, methylation of PTEN has been detected at a frequency of $2.9 \%$, with no association between methylation status and prognostic factors [24]. In cervical cancer, an association between PTEN methylation and prognostic factors has been found; however, higher frequencies of methylation were detected (58\%) [19].

In this series, the lack of association between gene methylation and major prognostic factors can be justified by the low frequency of methylation detected. PTEN mutation did not show an association with high-grade tumors or tumor recurrence in RCC [22]. Thus, mutation and methylation are not important mechanisms of gene dysregulation in RCC.

There were some limitations in our study, including the inherent problems of retrospective analysis. In the literature, there is no consensus in defining the cut-off for cases demonstrating high or low levels of methylation. It seems to us more appropriate to define the cases in relation to the level of methylation in normal tissue. To our knowledge, this is the first study to report the PTEN hypermethylation pattern in RCC.

\section{Conclusion}

Although the route of PTEN carcinogenesis is common in RCC, methylation in this series was infrequent and showed no adverse events, such as death, death due to renal cancer or tumor recurrence. This suggests involvement of other genes or mechanisms of genetic or epigenetic inactivation other than methylation in renal carcinogenesis.

\section{Conflicts of Interest}

The authors declare no conflicts of interest regarding the publication of this paper.

\section{References}

[1] Hyung, L.K., Seligson, D., Liu, X., et al. (2005) Tumors Using Markers to Predict the Survival of Metastatic Renal Cell Patients with Carcinoma. Journal of Urology, 173, 1496-1501. https://doi.org/10.1097/01.ju.0000154351.37249.f0

[2] Lam, J.S., Shvarts, O., Leppert, J.T., Figline, R.A. and Belldegrun, A.S. (2005) Renal Cell Carcinoma 2005: New Frontiers in Staging, Prognostication and Targeted Molecular Therapy. Journal of Urology, 173, 1853-1862. https://doi.org/10.1097/01.ju.0000165693.68449.c3 
[3] Sansal, I. and Sellers, W.R. (2004) The Biology and Clinical Relevance of the PTEN Tumor Supressor Pathway. Journal of Clinical Oncology, 22, 2954-2963. https://doi.org/10.1200/JCO.2004.02.141

[4] Sakurada, A., Suzuki, A., Sato, M., et al. (1997) Infrequent Genetic Alterations of the PTEN/MMAC1 Gene in Japanese Patients with Primary Cancers of the Breast, Lung, Pancreas, Kidney, and Ovary. Japanese Journal of Cancer Research, 88, 1025-1028. https://doi.org/10.1111/j.1349-7006.1997.tb00324.x

[5] Kisseljova, N.P. and Kisseljov, F.L. (2005) DNA Demethylation and Carcinogenesis. Biochemistry, 70, 743-752. https://doi.org/10.1007/s10541-005-0179-Z

[6] Kondo, K., Yao, M., Kobayashi, K., et al. (2001) PTEN/MMAC1/TEP1 Mutations in Human Primary Renal Cell Carcinomas and Renal Carcinoma Cell Lines. International Journal of Cancer, 91, 219-224. https://doi.org/10.1002/1097-0215(200002)9999:9999<::AID-IJC1034>3.0.CO;2-S

[7] Sükösd, F., Digon, B., Fischer, J., Pietsch, T. and Kovacs, G. (2001) Allelic Loss at 10q23.3 But Lack of Mutation of PTEN/MMAC1 in Renal Cell Carcinoma Chromophobia. Cancer Genetics and Cytogenetics, 128, 161-163. https://doi.org/10.1016/S0165-4608(01)00413-7

[8] Teng, D.H., Hu, R., Lin, H., et al. (1997) MMAC1/PTEN Mutations in Primary Tumor Specimens and Tumor Cell Lines. Cancer Research, 57, 5221-5225.

[9] Hara, S., Oya, M., Mizuno, R., Horiguchi, A., Marumo, K. and Murai, M. (2005) Akt Activation in Renal Cell Carcinoma: Contribution of a Decreased PTEN Expression and the Induction of Apoptosis by an Akt Inhibitor. Annals of Oncology, 16, 928-933. https://doi.org/10.1093/annonc/mdi182

[10] Lee, J.S., Kim, H.S., Kim, Y.B., Lee, M.C. and Park, C.S. (2003) Expression of PTEN in Renal Cell Carcinoma and Its Relation to Tumor Behavior and Growth. Journal of Surgical Oncology, 84, 166-172. https://doi.org/10.1002/jso.10302

[11] Figlin, R.A., de Souza, P., McDermott, D., et al. (2009) Analysis of PTEN and Hif-1alpha and the Correlation with Efficacy in Patients with Advanced Renal Cell Carcinoma Treated with Tensirolimus versus Interpheron-Alpha. Cancer, 115, 3651-3660. https://doi.org/10.1002/cncr.24438

[12] Fuhrman, S.A., Lasky, L.C. and Limas, C. (1982) Prognostic Significance of Morphologic Parameters in Renal Cell Carcinoma. The American Journal of Surgical Pathology, 6, 655-663. https://doi.org/10.1097/00000478-198210000-00007

[13] Bruder, E., Passera, O., Harms, D., et al. (2004) Morphologic and Molecular Characterization of Renal Cell Carcinoma in Children and Young Adults. The American Journal of Surgical Pathology, 28, 1117-1132. https://doi.org/10.1097/01.pas.0000131558.32412.40

[14] Sobin, L.H. and Wittekind, C. (2004) TNM Classification of Malignant Tumours. 6th Edition, INCA, Rio de Janeiro. https://doi.org/10.1002/0471463752

[15] Ehrich, M., Zoll, S., Sur, S. and van den Boom, D. (2007) A New Method for Accurate Assessment of DNA Quality after Bisulfite Treatment. Nucleic Acids Research, 35, 1-8. https://doi.org/10.1093/nar/gkl1134

[16] Sato, K., Tamura, G., Tsuchiya, T., et al. (2002) Analysis of Genetic and Epigenetic Alterations of the PTEN Gene in Gastric Cancer. Virchows Archiv, 440, 160-165. https://doi.org/10.1007/s004280100499

[17] Kishi, M., Nakamura, M., Nishimine, M., Ikuta, M., Kirita, T. and Konishi, N. (2004) Genetic and Epigenetic Alteration Profiles for Multiple Genes in Salivary Gland Carcinomas. Oral Oncology, 41, 161-169. https://doi.org/10.1016/j.oraloncology.2004.08.004 
[18] Baeza, N., Weller, M., Yonekawa, Y., Kleihues, P. and Ohgaki, H. (2003) PTEN Methylation and Expression in Glioblastomas. Acta Neuropathologica, 106, 479-485. https://doi.org/10.1007/s00401-003-0748-4

[19] Cheung, T.H., Lo, K.W., Yim, S.F., et al. (2004) Epigenetic and Genetic Alternation of PTEN in Cervical Neoplasm. Gynecologic Oncology, 93, 621-627. https://doi.org/10.1016/j.ygyno.2004.03.013

[20] Mirmohammadsadegh, A., Marini, A., Nambiar, S., et al. (2006) Epigenetic Silencing of the PTEN Gene in Melanoma. Cancer Research, 66, 6546-6552. https://doi.org/10.1158/0008-5472.CAN-06-0384

[21] Tam, K.F., Liu, V.W., Liu, S.S., et al. (2007) Methylation Profile in Benign, Borderline and Malignant Ovarian Tumors. Journal of Cancer Research and Clinical Oncology, 133, 331-341. https://doi.org/10.1007/s00432-006-0178-5

[22] Muggerud, A.A., Ronneberg, J.A., Wärnberg, F., et al. (2010) Frequent Aberrant DNA Methylation of ABCB1, FOXC1, PTEN and PPP2R2B in Ductal Carcinoma in Situ and Early Invasive Breast Cancer. Breast Cancer Research, 12, R3. https://doi.org/10.1186/bcr2466

[23] Yim, E.K., Peng, G., Dai, H., et al. (2009) Rak Functions as a Tumor Suppressor by Regulating PTEN Protein Stability and Functions. Cancer Cell, 15, 304-314. https://doi.org/10.1016/j.ccr.2009.02.012

[24] Kim, D.S., Lee, S.M., Yoon, G.S., Choi, J.E. and Park, J.Y. (2010) Infrequent Hypermethylation of the PTEN Gene in Korean Non-Small-Cell Lung Cancers. Cancer Science, 101, 568-572. https://doi.org/10.1111/j.1349-7006.2009.01406.x

[25] Shames, D.S., Minna, J.D. and Gazdar, S.F. (2007) Methods for Detecting DNA Methylation in Tumors: From Bench to Bedside. Cancer Letters, 251, 187-198. https://doi.org/10.1016/j.canlet.2006.10.014

[26] Zysman, M.A., Chapman, W. and Bapat, B. (2002) Considerations When Analyzing the Methylation Status of PTEN Tumor Suppressor Gene. The American Journal of Pathology, 160, 795-800. https://doi.org/10.1016/S0002-9440(10)64902-4

[27] Morita, R., Saito, S., Ishikawa, J., et al. (1991) Common Regions of Deletion on Chromosomes 5q, 6q, and 10q in Renal Cell Carcinoma. Cancer Research, 51, 5817-5820.

[28] Velickovic, M., Delahunt, B., McIver, B. and Grebe, S.K. (2002) Intragenic PTEN/ MMAC1 Loss of Heterozygosity in Conventional (Clear-Cell) Renal Cell Carcinoma is Associated with Poor Patient Prognosis. Modern Pathology, 15, 479-485. https://doi.org/10.1038/modpathol.3880551

[29] Zaman, M.S., Thamminana, S., Shahryari, V., et al. (2012) Inhibition of PTEN Gene Expression by Oncogenic miR-23b-3p in Renal Cancer. PLoS ONE, 7, e50203. https://doi.org/10.1371/journal.pone.0050203 